\title{
真円度および回転精度の多点法測定における 擬似逆行列を用いた計算処理の最適化に関する考察*
}

\author{
藤 巻 研 吾** 佐 瀬 浩 史 ${ }^{* * *}$ 三井公 之 ${ }^{\dagger}$
}

A Study on Algorithm Optimization of Multi-point Method

for Measurements of Roundness and Rotation Accuracy using Pseudo-inverse Matrix

Kengo FUJIMAKI, Hiroshi SASE and Kimiyuki MITSUI

The multi-point method using more than four displacement sensors requires selections from non-unique filters deriving out-of-roundness from sensor outputs in the case of the conventional calculation technique using inverse filtering with frequency analyses. This paper analyzes propagations of sensor noises in the calculation process of out-of-roundness estimation, and shows that the calculation technique of multi-point method using pseudo-inverse matrix optimizes the calculation process and minimizes propagations of random noises occurring in sensor outputs without laborious calculations in search of the optimized filter.

Key words: multi-point method, three-point method, roundness, rotation accuracy, pseudo-inverse matrix

\section{1. 緒言}

円筒や球などをスピンドルにより回転させて断面形状の真円 度を測定する場合, 回転に伴うスピンドルの振れは, 断面形状 の測定結果を歪ませ, 真円度の測定精度を低下させる. 3 点法は, センサを 3 本用いて測定を行い, 収録データに一定の計算処理 をすることで，スピンドルの振れの影響を受けることなく円筒 や球の断面形状を得ることができる超精密測定法である ${ }^{1) ~ 3) . ~}$ センサ数を 3 本に限定せずに一般化し, 多点法とも呼ばれる. また, 得られた断面形状を用いてセンサ出力を補正することで, 高精度な回転精度測定を行うことも可能である ${ }^{4}$. この方法を応 用して様々な真円度・回転精度測定システムが提案されており 5) 14)，さらに, 計算処理過程の誤差解析も行われている ${ }^{15) ~ 19)}$

3 点法の場合, 取り付けたセンサの角度に対して, 計算処理に 用いるフィルタは一意に求まるため, 計算手順が非常に明解で ある. しかし，4本以上のセンサを用いた多点法では，そのフィ ルタは一意には求まらず, 測定者がフィルタを選定する必要が ある. ただし，それぞれフィルタによって処理結果へのセンサ ノイズの伝播量が異なるため, フィルタの選定は慎重に行う必 要があり, 特にセンサノイズの伝播を最小にするフィルタを選 定するには，複雑で膨大な計算が必要となる.

一方，V ブロック法真円度測定における逆行列を用いた計算 方法 ${ }^{20)}$ を一般化して, 3 点法における擬似逆行列を用いた計算方 法が提案されている ${ }^{21)}$. この方法は，一般的に使用されている 周波数解析を用いた逆フィルタリング処理による計算方法と比 較して, 同じ処理結果を得られることが確認されており, 簡素 なプログラムで 3 点法の計算処理を行うことができる.

本研究では，この擬似逆行列を用いる計算方法が，これまで 計算処理に用いるフィルタの選定に膨大な計算を必要としてい た 4 本以上のセンサを用いる多点法において, 簡単なアルゴリ ズムで計算処理を最適化し，処理結果へのセンサノイズの伝播 量を最小にすることを明らかにしたので，以下に報告する.

* 原稿受付 平成 18 年 11 月 29 日.

* 学生会員 慶應義塾大学大学院（神奈川県横浜市港北区日吉 3-14-1)

*** 慶應義塾大学大学院（神奈川県横浜市港北区日吉 3-14-1)

$\dagger$ 正会員 慶應義塾大学 (神奈川県横浜市港北区日吉 3-14-1)

\section{2. 原 理}

\section{1 逆フィルタリング処理を用いた計算方法}

まず，多点法において，一般的に使用されている周波数解析 を用いた逆フィルタリング処理による計算方法について述べる。 図 1 に示すように, スピンドルに取り付けられた円筒の周りに $n$ 本のセンサ (変位センサ) をそれぞれセンサ角度 $\phi_{i}(i=1,2, \ldots, n)$ として配置するとき, 回転角度 $\theta$ における $X, Y$ 方向のスピンド ルのラジアル振れを $x(\theta), y(\theta)$, 円筒の断面形状（真円からの ずれ）を $r(\theta)$ とすると, センサ $i(i=1,2, \ldots, n)$ の出力 $v_{i}(\theta)$ は以 下のように表される.

$$
v_{i}(\theta)=r\left(\theta+\phi_{i}\right)+x(\theta) \sin \phi_{i}+y(\theta) \cos \phi_{i}
$$
ここで,

$$
\sum_{i=1}^{n} w_{i} \sin \phi_{i}=0, \quad \sum_{i=1}^{n} w_{i} \cos \phi_{i}=0
$$

をともに満たす重み係数 $w_{i}(i=1,2, \ldots, n)$ を用いて, センサ出力 $v_{i}(\theta)$ の重み加算 $s(\theta)$ を求めると

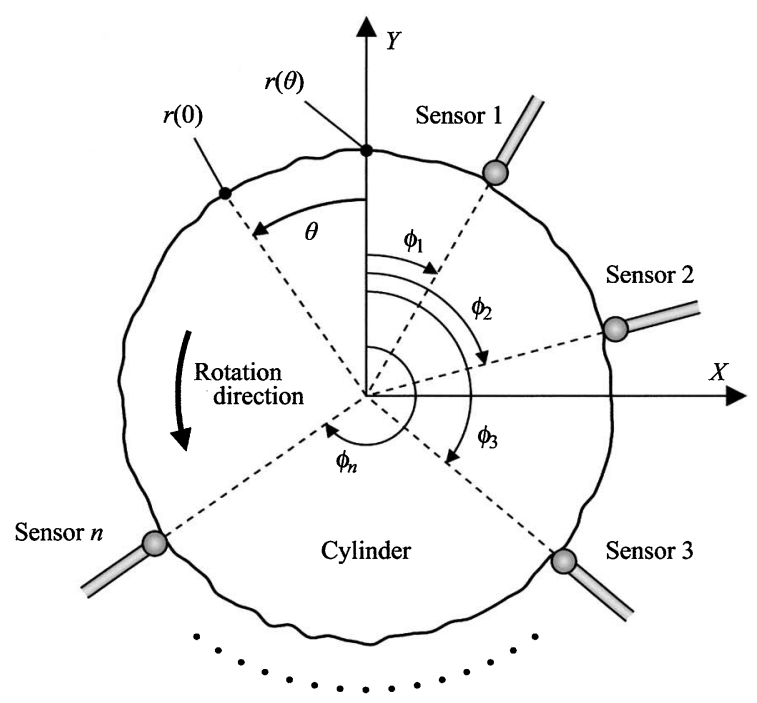

Fig.1 Sensor layout of multi-point method 


$$
s(\theta)=\sum_{i=1}^{n} w_{i} v_{i}(\theta)=\sum_{i=1}^{n} w_{i} r\left(\theta+\phi_{i}\right)
$$

となり, $s(\theta)$ はラジアル振れ $x(\theta), y(\theta)$ に依存しない值となる. よって, スピンドルの 1 回転を基本周期とする周波数 $k$ (単位 upr : undulation per revolution）を用いて, 入力 $r(\theta)$, 出力 $s(\theta)$ の フィルタの伝達関数 $H(j k)$ は,

$$
H(j k)=\sum_{i=1}^{n} w_{i} \exp \left(j k \phi_{i}\right)
$$

と表すことができる.よって，この逆フィルタ $H^{-1}(j k)$ に重み 加算 $s(\theta)$ を通すことで $r(\theta)$ を推定することができる. ただし, センサは変位量を計っているため, 直流成分 $(k=0 \mathrm{upr})$ は意味 を持たず，また，円筒の断面形状の $k=1$ upr 成分は，円筒の偏 心と等価であり, 通常, それはラジアル振れに含めるため, 上 述の逆フィルタリング処理は $k=0,1$ upr 以外の周波数に限られ る. さらに, ゼロ割とはならないように2upr から処理する最大 周波数 $k_{\max }$ までにおいて, $|H(j k)| \neq 0$ となるセンサ角度 $\phi_{i}$ を選 択する必要がある. また, 推定された断面形状をセンサ出力か ら差し引くことでラジアル振れを得ることができる. 以下, 重 み加算したデータを逆フィルタリング処理するこの計算方法を 逆フィルタリング法 (Inverse filtering method) と呼ぶ.

多点法を用いた実際の測定では, 静電容量型変位計を用いて GND から絶縁した円筒を測定する場合や NC 工作機械に搭載さ れたスピンドルにおいて測定を行う場合など, 高 SN 比のセンサ 出力を得られないケースがあり, 計算処理においてセンサノイ ズの伝播を抑えることは非常に重要である.ここで, センサ出 力 $v_{i}(\theta) \quad(i=1,2, \ldots, n)$ から重み加算 $s(\theta)$ へのランダムノイズ (ホワイトガウスノイズ)の伝播を正規化するために,

$$
\sum_{i=1}^{n} w_{i}^{2}=1
$$

とおく.このとき, センサ出力 $v_{i}(\theta)$ 上のノイズと重み加算 $s(\theta)$ 上のノイズは, パワースペクトルにおいて等価と見なすことが できる. よって, $r(\theta)$ の推定值におけるセンサノイズのゲイン 特性は周波数 $k$ において $\left|H^{-1}(j k)\right|$ となる. ホワイトガウスノイ ズは各周波数ごとに一様のパワースペクトルを持っているため, 2 upr から処理する最大周波数 $k_{\max }$ までの周波数帯域における平 均的なノイズゲイン $G_{a v e}$ は以下のように表される.

$$
G_{a v e}=\sqrt{\frac{1}{k_{\max }-1} \sum_{k=2}^{k_{\max }}\left|H^{-1}(j k)\right|^{2}}
$$

3 点法 $(n=3)$ であれば, 重み係数 $w_{i}$ の正負がすべて反転し ただけの解を 1 つと見なすと, 式(2),(3),(6)を満たす重み係数 $w_{i}$ は一意に求まるため, センサ角度 $\phi_{i}$ を選択すると重み係数 $w_{i}$ が 決定し, 逆フィルタの伝達関数 $H^{-1}(j k)$ も決定する. 一方, セ ンサ数 $n$ を 4 以上とすると, 式(2),(3),(6)の 3 式を満たす重み係 数 $w_{i}$ は一意には求まらない. 寸なわち, センサ出力 $v_{i}(\theta)$ から 断面形状 $r(\theta)$ を推定するフィルタは無数に存在することにな る.たとえば, 4 点法においてセンサ角度を $\left(\phi_{1}, \phi_{2}, \phi_{3}, \phi_{4}\right)=\left(0^{\circ}, 23^{\circ}\right.$, $\left.90^{\circ}, 117^{\circ}\right)$ とするとき, 重み係数 $\left(w_{1}, w_{2}, w_{3}, w_{4}\right)=(0.657,-0.455$, $-0.291,0.526)$ および $(-0.062,0.370,-0.693,0.615)$ はともに式 (2),(3),(6)を満たす．それらを用いて, 標準偏差 $0.1 \mu \mathrm{m}$ のランダ ムノイズ (ホワイトガウスノイズ) を含む 4 つのセンサ信号か ら $H^{-1}(j k)$ により推定される断面形状をシミュレーションする と，それぞれ図 2 の(1), (2)の点線に示すようになる. どちらも 実線で示されている真值と近い結果が得られているが, 真值に 対する標準偏差 $\sigma$ は異なっている. よって, 同じ 4 つのセンサ 出力を用いても, 計算処理方法によってセンサノイズの伝播特 性が異なることがわかる. また，それぞれの逆フィルタのノイ ズゲイン $\left|H^{-1}(j k)\right|$ は図 3 に示すようになり, 周波数ごとにその 優劣は異なることがわかる. 上記 2 組の重み係数のうち, 周波

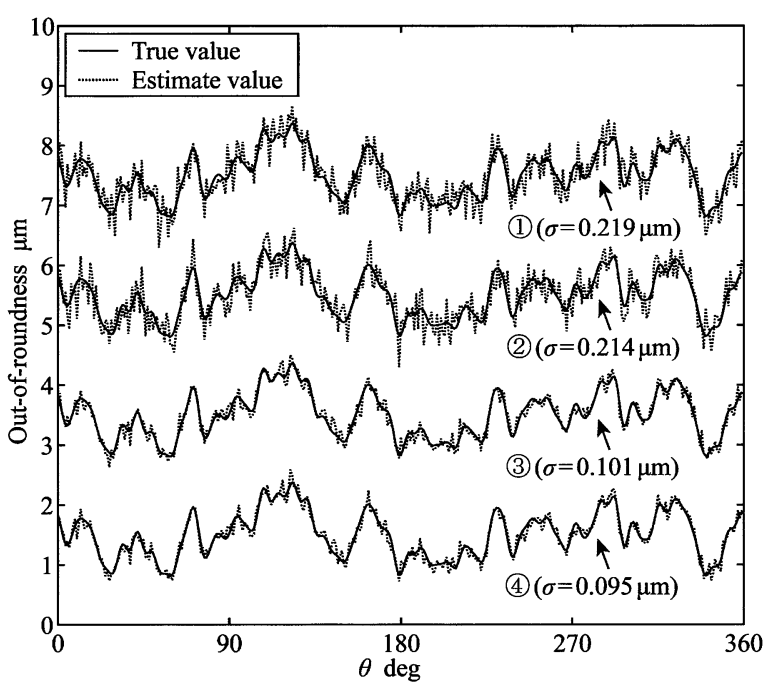

Fig.2 Out-of-roundness estimation using inverse filtering method (Simulation of 4-point method, $\left.\left(\phi_{1}, \phi_{2}, \phi_{3}, \phi_{4}\right)=\left(0^{\circ}, 23^{\circ}, 90^{\circ}, 117^{\circ}\right)\right)$

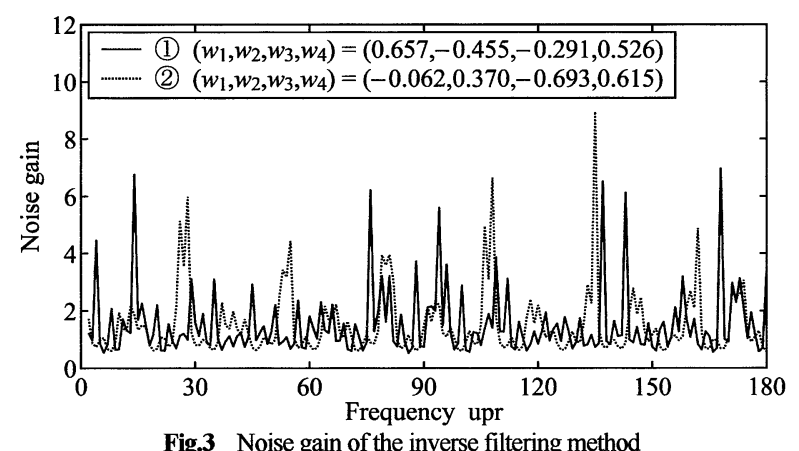

数ごとにノイズゲインの小さい方を選択して計算処理を行い, 推定断面形状を合成すると, 図 2 の(3)示すようにセンサノイ ズの伝播のより小さい結果が得られる.さらに, 式(2),(3),(6)を 満たす上記 2 組以外の重み係数（実数係数）においても, 同様 のことを行えば, 図 2 の(4)に示すように，さらにノイズの伝播 を小さく抑えることができる.このことから，文献 6)でも提案 されているように, センサノイズの伝播を最小に抑えるには, 式(2),(3),(6)を満たし, かつ $\left|H^{-1}(j k)\right|$ を最小にする重み係数 $w_{i}$ を 各周波数ごとに求める必要があることがわかる. しかし, 各周 波数ごとに最適な重み係数 $w_{i}$ を求めるのは多大な計算時間を 要し, センサ数 $n$ が増えるほど, ますます困難になる.

\section{2 擬似逆行列を用いた計算方法}

ここでは，多点法における擬似逆行列を用いた計算方法につ いて述べる. センサ数を $n, 1$ 回転当たりのサンプル数を $M$ と し, センサ角度 $\phi_{i} \quad(i=1,2, \ldots, n)$ が回転角のサンプリング間隔 $2 \pi / M$ の $P_{i}$ 倍であるとする. サンプリングタイミング $m=0,1, \ldots, M-1$ におけるセンサ $i$ の出力 $v_{i,(m)}$ は, 式(1)の断面形 状 $r(\theta)$ およびラジアル振れ $x(\theta), y(\theta)$ をそれぞれ離散時間デ 一タ $r_{(m)}, x_{(m)}, y_{(m)}$ とおいて

$$
v_{i,(m)}=r_{\left(m+P_{i}\right)}+x_{(m)} \sin \phi_{i}+y_{(m)} \cos \phi_{i}
$$

と表すことができる.ここで,

$$
\begin{aligned}
& \mathbf{V}_{i}=\left[\begin{array}{llll}
v_{i,(0)} & v_{i,(1)} & \cdots & v_{i,(M-1)}
\end{array}\right]^{T} \\
& \mathbf{R}=\left[\begin{array}{llll}
r_{(0)} & r_{(1)} & \cdots & r_{(M-1)}
\end{array}\right]^{T} \\
& \mathbf{X}=\left[\begin{array}{llll}
x_{(0)} & x_{(1)} & \cdots & x_{(M-1)}
\end{array}\right]^{T} \\
& \mathbf{Y}=\left[\begin{array}{llll}
y_{(0)} & y_{(1)} & \cdots & y_{(M-1)}
\end{array}\right]^{T}
\end{aligned}
$$




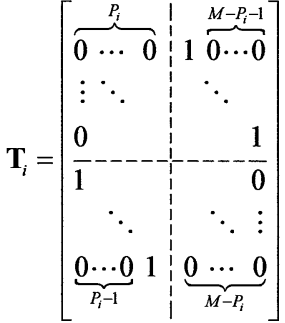

$$
\begin{aligned}
& \cos \Theta=\left[\begin{array}{c}
\cos (2 \pi \cdot 0 / M) \\
\cos (2 \pi \cdot 1 / M) \\
\vdots \\
\cos (2 \pi \cdot(M-1) / M)
\end{array}\right]^{T} \\
& \sin \Theta=\left[\begin{array}{c}
\sin (2 \pi \cdot 0 / M) \\
\sin (2 \pi \cdot 1 / M) \\
\vdots \\
\sin (2 \pi \cdot(M-1) / M)
\end{array}\right]^{T}
\end{aligned}
$$

とおき,さらに $\mathbf{O}_{1 \times M}$ を 0 の要素からなる $1 \times M$ の横ベクトル $\mathbf{E}$ を $M \times M$ の単位行列とおいて

$$
\mathbf{V}=\left[\begin{array}{c}
\mathbf{V}_{1} \\
\mathbf{V}_{2} \\
\vdots \\
\mathbf{V}_{n} \\
0 \\
0
\end{array}\right], \mathbf{Z}=\left[\begin{array}{c}
\mathbf{R} \\
\mathbf{X} \\
\mathbf{Y}
\end{array}\right], \mathbf{A}=\left[\begin{array}{ccc}
\mathbf{T}_{1} & \sin \phi_{1} \mathbf{E} & \cos \phi_{1} \mathbf{E} \\
\mathbf{T}_{2} & \sin \phi_{2} \mathbf{E} & \cos \phi_{2} \mathbf{E} \\
\vdots & \vdots & \vdots \\
\mathbf{T}_{n} & \sin \phi_{n} \mathbf{E} & \cos \phi_{n} \mathbf{E} \\
\cos \Theta & \mathbf{O}_{1 \times M} & \mathbf{O}_{1 \times M} \\
\sin \Theta & \mathbf{O}_{1 \times M} & \mathbf{O}_{1 \times M}
\end{array}\right]
$$

とすると， $m=0,1, \ldots, M-1$ において式(8)が成り立つとして, 以 下のように表すことができる.

$$
\mathbf{V}=\mathbf{A Z}
$$

ただし， V の下 2 つ要素および $\mathbf{A}$ の下 2 行は, 文献 21)でも 述べられているように，ラジアル振れの lupr 成分と断面形状の lupr 成分が分離できないことに起因したランク落ちを補うため, 断面形状 $r_{(m)}$ に lupr 成分がないとして拘束条件を加えたもので

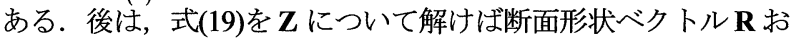
よびラジアル振れベクトル $\mathbf{X}, \mathbf{Y}$ を得ることができる.このとき， (たとえば, 4 点法において $\left(\phi_{1}, \phi_{2}, \phi_{3}, \phi_{4}\right)=\left(0^{\circ}, 90^{\circ}, 180^{\circ}, 270^{\circ}\right)$ などのような）特異なセンサ角度を選択しない限り， $(n M+2) \times 3 M$ の行列 $\mathbf{A}$ は $\operatorname{rank}(\mathbf{A})=3 M$ であるため, $\mathbf{A}$ の擬似 逆行列は,

$$
\mathbf{A}^{+}=\left(\mathbf{A}^{T} \mathbf{A}\right)^{-1} \mathbf{A}^{T}
$$

と表される. この擬似逆行列 $\mathbf{A}^{+}$は， $\mathbf{A}^{+} \mathbf{V}$ を $\mathbf{Z}$ の最小二乗解と して与えるもので, 寸なわち $\left\|\mathbf{A}^{+} \mathbf{V}-\mathbf{Z}\right\|$ を最小にする行列である. ここで, センサノイズの標準偏差を $0.1 \mu \mathrm{m}$, センサ角度を $\left(\phi_{1}, \phi_{2}, \phi_{3}, \phi_{4}\right)=\left(0^{\circ}, 23^{\circ}, 90^{\circ}, 117^{\circ}\right)$ とした前節 2.1 と同じセンサ出 力を用いて 4 点法による断面形状の推定をシミュレーションす ると，図 4 に示すようになる. これより，文献 6)に提案されて いる周波数ごとに最適な重み係数を求めて逆フィルタリング法 により計算する方法（図 2 の(4)）と比べても，よりセンサノイ ズの伝播の小さい結果が得られることがわかる. よって，この 擬似逆行列による計算方法（以下，これを擬似逆行列法（Pinv matrix method）と呼ぶ.）を用いれば, センサ数が 4 本以上の多 点法においては一意ではない計算処理を最適化し, 計算結果に 対して, センサに生じるランダムノイズ（ホワイトガウスノイ ズ) の伝播を最小に抑えることができると考えられる. ただし， 擬似逆行列法の計算を $\mathrm{PC}$ 上で行う場合, 特に式(20)の逆行列計算 において, 多大な計算量およびメモリを必要とする. そのため, 逆フィルタリング法と比較して, 擬似逆行列法は計算速度および PC 上のメモリ使用量の点で不利である.

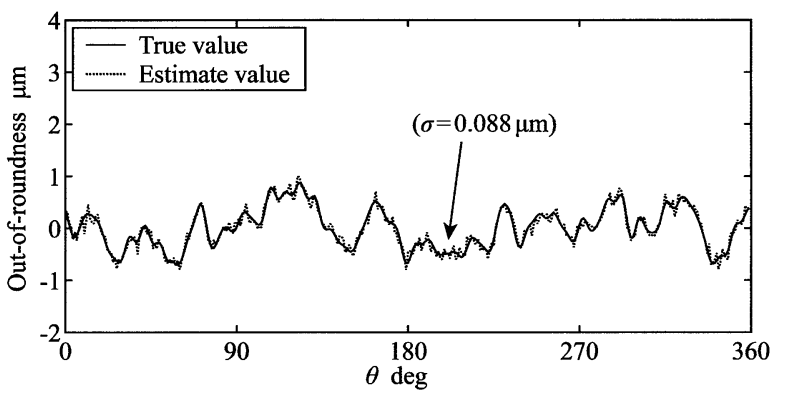

Fig.4 Out-of-roundness estimation using pinv matrix method (Simulation of 4-point method, $\left.\left(\phi_{1}, \phi_{2}, \phi_{3}, \phi_{4}\right)=\left(0^{\circ}, 23^{\circ}, 90^{\circ}, 117^{\circ}\right)\right)$

なお，ここではセンサ角度をサンプリング間隔の整数倍であ ると仮定して，断面形状をセンサ角度 $\phi_{i}$ だけ位相シフトさせる 行列 $\mathbf{T}_{i}$ を 0 と 1 の要素のみで表した. これは, 断面形状 $\mathbf{R}$ のナ イキスト周波数 $k=M / 2$ 以上の成分が，サンプリング間隔の整 数倍以外に位相シフトできないことに因るものである. センサ 出力がサンプリング定理を満たし，かつ 1 回転当たりのサンプ 儿数 $M$ が奇数の場合に限れば, 推定する断面形状 $\mathbf{R}$ にナイキス 卜周波数以上の成分は存在しないため, サンプリング間隔の整 数倍以外に位相シフトさせることが可能である.このとき，周 波数解析を必要としないという擬似逆行列法の利点は薄れるが， 離散フーリエ変換の行列 $\mathbf{W}$ および周波数ごとにセンサ角度 $\phi_{i}$ に応じて位相シフトさせる行列 $\mathbf{L}_{i}$ を

$$
\begin{aligned}
& \mathbf{W}=\left[\begin{array}{cccc}
e^{-2 \pi j \cdot 0 \cdot 0 / M} & e^{-2 \pi j \cdot 0 \cdot 1 / M} & \cdots & e^{-2 \pi j \cdot 0 \cdot(M-1) / M} \\
e^{-2 \pi j \cdot 1 \cdot 0 / M} & e^{-2 \pi j \cdot 1 \cdot 1 / M} & \cdots & e^{-2 \pi j \cdot 1 \cdot(M-1) / M} \\
\vdots & \vdots & \ddots & \vdots \\
e^{-2 \pi j \cdot(M-1) \cdot 0 / M} & e^{-2 \pi j \cdot(M-1) \cdot 1 / M} & \cdots & e^{-2 \pi j \cdot(M-1) \cdot(M-1) / M}
\end{array}\right] \\
& \mathbf{L}_{i}=\operatorname{diag}\left(e^{j 0 \phi_{i}}, e^{j l \phi_{i}}, \cdots, e^{j \frac{M-1}{2} \phi_{i}}, e^{-j \frac{M-1}{2} \phi_{i}}, \cdots, e^{-j 2 \phi_{i}}, e^{-j 1 \phi_{i}}\right) \\
& \mathbf{T}_{i}=\mathbf{W}^{-1} \mathbf{L}_{i} \mathbf{W}
\end{aligned}
$$$$
\text { とおいて, } \mathbf{T}_{i} \text { は }
$$

と表すことができる. 擬似逆行列法は PC 上のメモリを多く使用 することから，推定する断面形状の最大周波数に応じてセンサ 出力をあらかじめダウンサンプリングして, 計算する行列のサ イズを極力小さくした方がよい，この多くの場合，センサ角度 はサンプリング間隔の整数倍とはならないため，たとえば，断 面形状 $\mathbf{R}$ を周波数 $k_{\max }=10 \mathrm{upr}$ まで計算する場合には $M=21$, $k_{\max }=100 \mathrm{upr}$ まで計算する場合には $M=201$ といった具合に, 1 回転あたりのサンプル数を奇数にして式(23)を用いて計算する 必要がある.

\section{3. 解 析}

\section{1 各周波数におけるノイズゲインの関係}

多点法において，ラジアル振れは推定された断面形状を用い てセンサ出力を補正するだけであるので，ここではセンサ出力 から推定される断面形状へのランダムノイズ（ホワイトガウシ アンノイズ）の伝播特性について詳しく解析を行う.

まず, 3 点法 $(n=3)$ について, 上述した逆フィルタリング 法と擬似逆行列法を比較する. 1 回転当たりのサンプル数を $M=360,3$ 本のセンサ角度を $\left(\phi_{1}, \phi_{2}, \phi_{3}\right)=\left(0^{\circ}, 23^{\circ}, 90^{\circ}\right)$ とすると, 逆フィルタリング法と擬似逆行列法によるランダムノイズのゲ イン特性は図 5(a)に示すようになり，両者は完全に一致する. なお，逆フィルタリング法のノイズゲインは $\left|H^{-1}(j k)\right|$ を用い， 擬似逆行列法のノイズゲインは，擬似逆行列 $\mathbf{A}^{+}$が一種の FIR

(有限インパルス応答) フィルタであることから， $\mathbf{A}^{+}$の要素の うち $\mathbf{R}$ に関する部分を $\mathrm{z}$ 変換することで求めた. この結果より, 


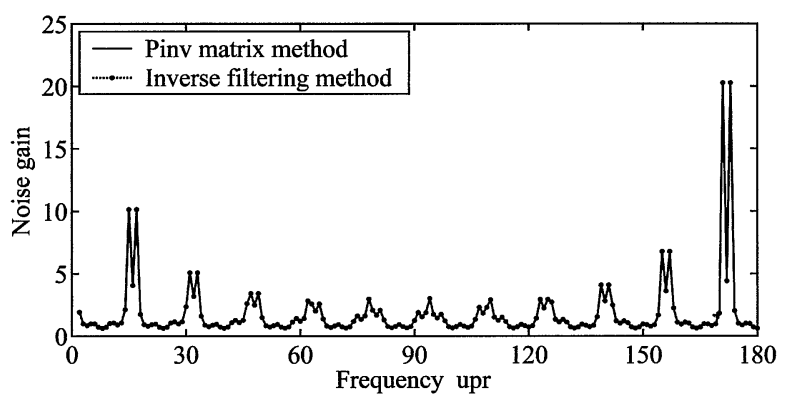

(a) 3-point method $\left(0^{\circ}, 23^{\circ}, 90^{\circ}\right)$

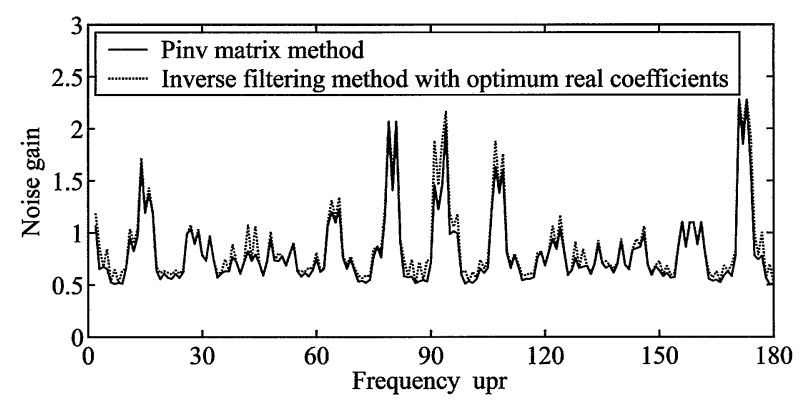

(b) 4-point method $\left(0^{\circ}, 23^{\circ}, 90^{\circ}, 117^{\circ}\right)$

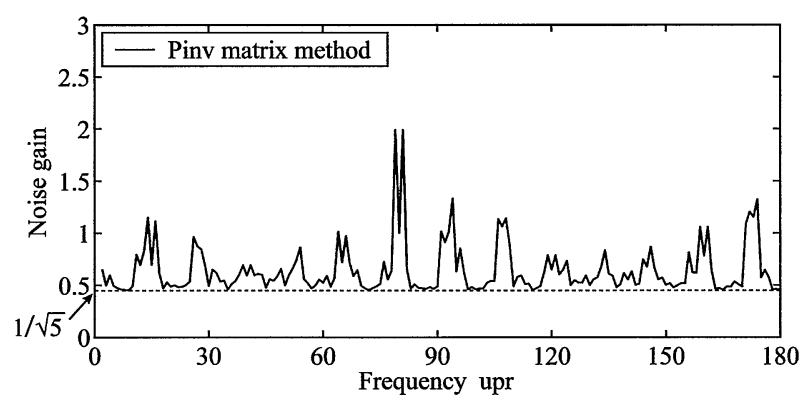

(c) 5-point method $\left(0^{\circ}, 23^{\circ}, 90^{\circ}, 117^{\circ}, 144^{\circ}\right)$

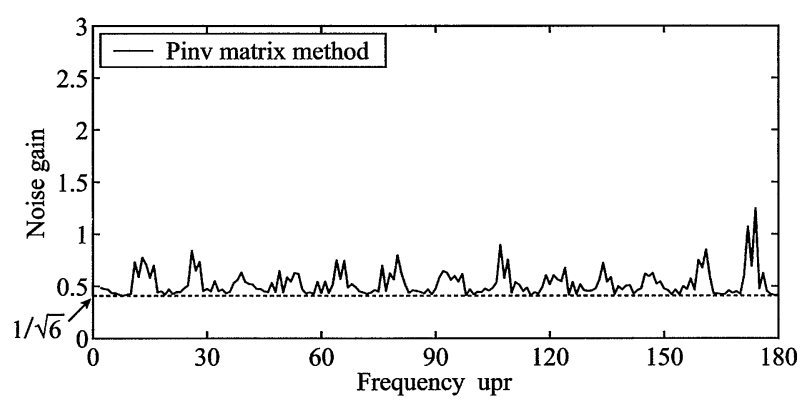

(d) 6-point method $\left(0^{\circ}, 23^{\circ}, 90^{\circ}, 117^{\circ}, 144^{\circ}, 173^{\circ}\right)$

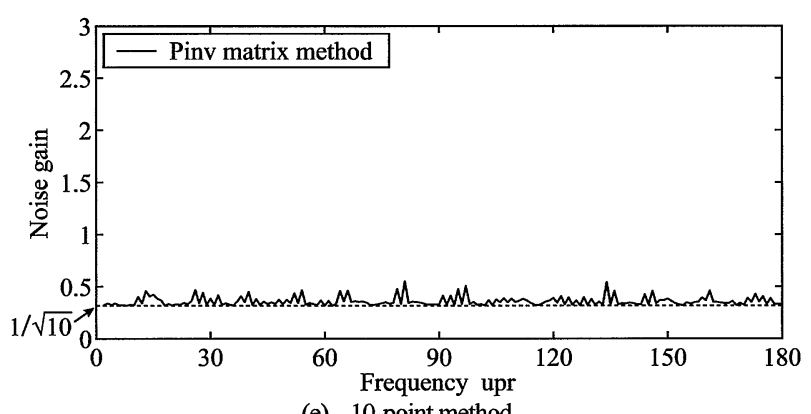

(e) 10-point method

$\left(0^{\circ}, 23^{\circ}, 90^{\circ}, 117^{\circ}, 144^{\circ}, 173^{\circ}, 199^{\circ}, 221^{\circ}, 266^{\circ}, 293^{\circ}\right)$

Fig.5 Comparison of noise gains ( $M=360)$
センサが 3 本の場合には, センサ出力から断面形状を推定する フィルタは一意に求まるため, 2 つの方法は計算手順が異なるだ けで，結果的には同じ処理を行っていることがわかる.

次に, 上で用いた 3 本のセンサに， $\phi_{4}=117^{\circ}$ の 4 本目のセン サを加えた 4 点法 $(n=4)$ について検討する.ここでは, 文献 6)で提案されているように, 各周波数ごとにノイズゲインを最小 にする重み係数を求めて, 逆フィルタリング法により計算する 場合と比較する. 結果は図 5(b)に示すようになり, すべての周 波数において, 最適な重み係数を求めて逆フィルタリング法を 用いるよりも，擬似逆行列法の方がより小さいノイズゲインを 実現できることがわかる，これは，逆フィルタリング法におい て最適な重み係数を実数の範囲で求めているためであり, 各周 波数の複素フーリ工係数ごとに考える場合, 重み係数は複素数 を取りうる. このとき，擬似逆行列法により求めた $\mathbf{A}^{+}$を基にし て, 周波数 $k=2$ upr における重み係数を求めると $\left(w_{1}, w_{2}, w_{3}\right.$, $\left.w_{4}\right)=(0.534,-0.348-0.164 j,-0.295+0.360 j, 0.484-0.332 j)$ となって おり，これらの複素係数は確かに式(2),(3),(6)を満たす.

同様に，5本目のセンサを $\phi_{5}=144^{\circ} ， 6$ 本目のセンサを $\phi_{6}=173^{\circ}, 7 \sim 10$ 本目のセンサを $\left(\phi_{7}, \phi_{8}, \phi_{9}, \phi_{10}\right)=\left(199^{\circ}, 221^{\circ}\right.$, $266^{\circ}, 293^{\circ}$ ) として加え, それぞれ 5 点法, 6 点法, 10 点法として, 擬似逆行列法におけるノイズゲインの特性を求めると, 図 5(c),(d),(e)に示すようになる.これらより，センサ数を増やすほ どノイズゲインの大きな周波数は少なくなるが，その值は常に $1 / \sqrt{n}$ 以上であることがわかる.これは, ランダムノイズを含む $n$ 本のセンサ出力信号を同期加算する以上には SN 比を向上す ることができないことに因るものである.

\section{2 センサ角度とノイズゲインの関係}

ここでは, 多点法において擬似逆行列法を用いて計算を行う 場合のセンサ角度とノイズゲインの関係の例として, 4 点法 $(n=4)$ においてセンサ角度を $\phi_{1}=0^{\circ} ， \phi_{2}=90^{\circ}$ としたときに ついて検討する. 処理する最大周波数 $k_{\text {max }}$ を 10upr, 15upr, 20upr としたときの, センサ角度 $\phi_{3}, \phi_{4}$ に対する擬似逆行列法の平均ノ イズゲインの分布を図 6 に示す.これは, 各周波数のノイズゲ インの平均自乗根 (自乗平均平方根) により計算しており, 2upr から $k_{\max }$ までの周波数において一様なパワースペクトルを持つ センサノイズに対するゲインを表している.この分布から， $k_{\max }$ が大きくなるほど, 式(19)の $\mathbf{A}$ のランクが $3 M$ から落ちて平均) イズゲインが無限大に発散する特異点の数が増え, また, その 近傍のセンサ角度でもノイズの伝播が大きいことがわかる．一 方, 特異点ないしその近傍のセンサ角度を選択しない限り, 平 均のノイズゲインは概ね 1 を下回っており, センサの SN 比を低 下させずに計算処理できることがわかる.

\section{4. 結言}

多点法測定における擬似逆行列法について，解析およびシミ ユレーションを行い，センサに生じるランダムノイズ（ホワイ トガウスノイズ）の伝播特性について検討した. 本研究により 得られた結果をまとめ, 以下に示す.

（1）擬似逆行列法は，4 本以上のセンサを用いる場合, 本来, 一意とはならない多点法の計算処理を最適化し，測定した 断面形状の推定結果に対して, 各センサ上のランダムノイ ズの伝播を最小に抑えて処理を行うことができる. その際, 実数の範囲で最適な重み係数を求め, 逆フィルタリング法 を用いて計算する方法よりも, 擬似逆行列法は, さらに最 適化した計算処理を実現する。

(2) センサ数が $n$ 本のとき，たとえ多点法の計算処理を最適化 したとしても，センサに生じるランダムノイズの各周波数 におけるゲインは $1 / \sqrt{n}$ を下回ることはない. 


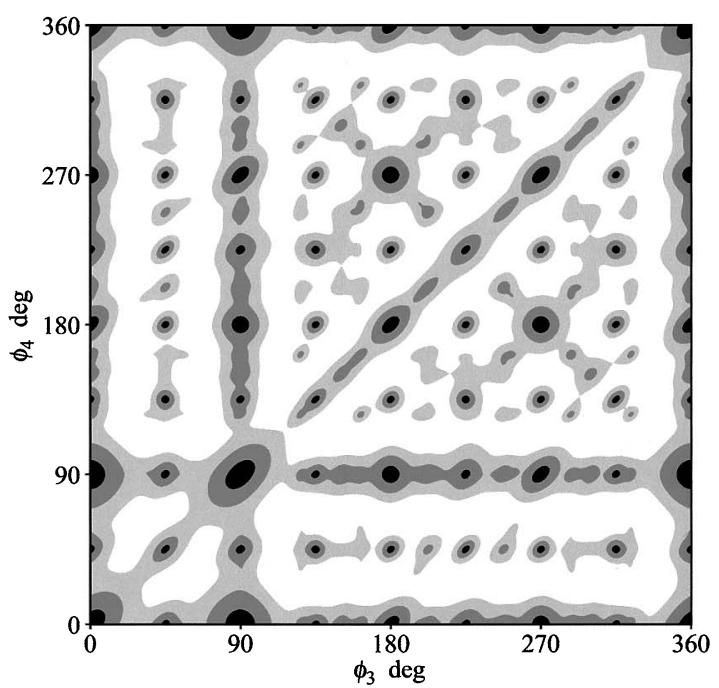

(a) $k_{\max }=10$ upr

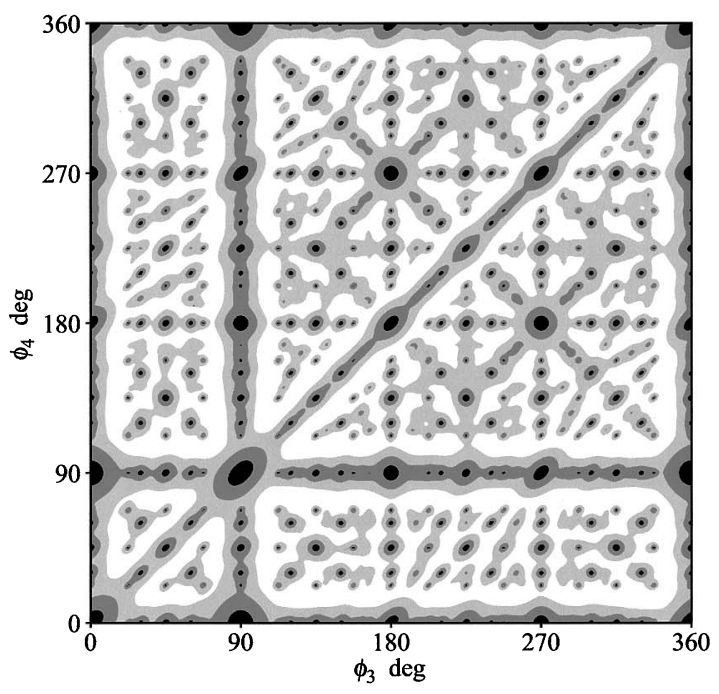

(b) $k_{\max }=15$ upr

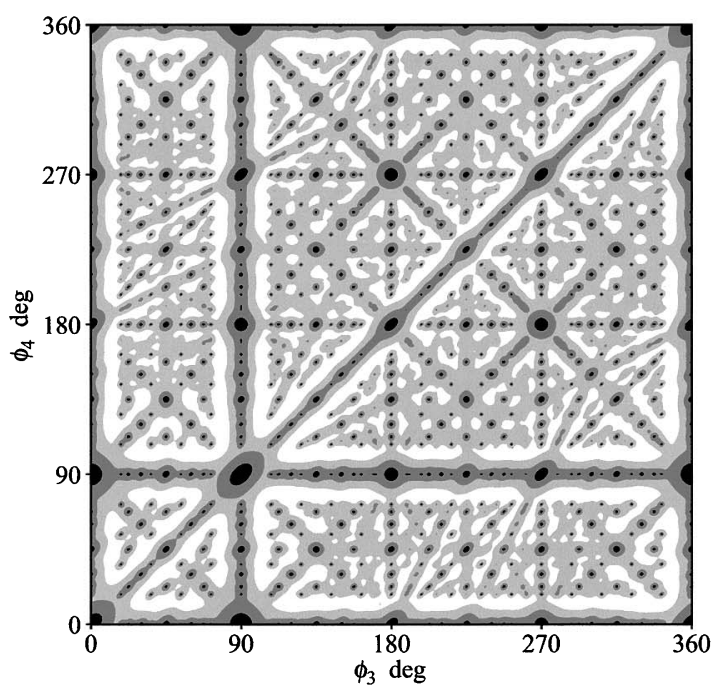

(c) $k_{\max }=20$ upr

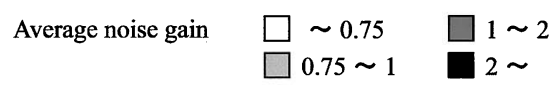

Fig.6 Distribution of average noise gain between 2 upr and $k_{\max }$ $\left(\phi_{1}=0^{\circ}, \phi_{2}=90^{\circ}\right)$
（3）擬似逆行列法は，PC 上のメモリを多く使用することから， 推定する断面形状に要求される最大周波数に合わせて，あ らかじめセンサ出力のデータをダウンサンプリングし, 計 算する擬似逆行列のサイズを小さくする必要がある，その とき, 1 回転当たりのサンプル数は奇数とする.

\section{考 文 献}

1）青木保雄，大園成夫：3 点法真円度測定法の一考察，精密機械，32, $12(1966) 831$.

2) D. J. Whitehouse : Some theoretical aspects of error separation techniques in surface metrology, J. Phys. E, 9, 7 (1976) 531.

3) D. Moore : Design considerations in multiprobe roundness measurement, $\mathrm{J}$. Phys. E, 22, 6 (1989) 339.

4) 三井公之: 精度診断技術の研究 3 点式主軸回転精度測定装置の開発, 日本機械学会論文集（C 編），48，425(1982) 115

5) H. Shinno, K. Mitsui, Y. Tatsue N. Tanaka, T. Omino and T. Tabata : A new method for evaluating error motion of ultra precision spindle, CIRP Ann., 36, $1(1987) 381$.

6) G. X. Zhang and R. K. Wang : Four-point method of roundness and spindle error measurements, CIRP Ann., 42, 1 (1993) 593.

7) 島筒博章, 藤田昭次, 須藤勝蔵, 垣野義昭 : 3 点法による寸法·形状測 定に関する研究 (第 1 報) 工作機械上での大口径外径測定装置の開発, 精密工学会誌, 61，3(1995) 363.

8）鴻巣健治，小野寺克博，富田宏貴，佐藤建吉 : 円形状の機上測定シス テム，日本機械学会論文集（C 編），64，617(1998) 336

9）横田篤也, 山田隆一, 柳和久: 光学式仮想 Vブロック方式による真円 度評価システムの開発 (第 2 報) 開発システムの性能評価, 精密工学 会誌, 67, $3(2001) 483$.

10）小倉一朗, 岡崎祐一: 多点法による工作機械回転主軸のアキシャルお よびアンギュラモーションエラーの精密測定に関する研究, 精密工学 会誌, 67, 7(2001) 1120 .

11) M. J. Jansen, P. H. J. Schellekens and B. De Veer : Advanced spindle runout-roundness separation method Advanced Mathematical and Computational Tools in Metrology V, 57, (2001) 212.

12）高偉, 佐藤栄二郎, 大沼孝真, 清野慧 : 角度 3 点法による真円度と回 転誤差測定に関する研究 第 1 報 角度 3 点法による真円度測定, 精密 工学会誌, 68, 9(2002) 1195 .

13) G.B. Jeong, D. H. Kim and D. Y. Jang : Real time monitoring and diagnosis system development in turning through measuring a roundness error based on three-point method, Int. J. Machine Tools and Manufacture, 45, 12-13 (2005)1494.

14）鈴木紀和：高速スピンドルの動特性評価，機械と工具，49，12(2005) 77 .

15）加藤秀雄, 野村雄一郎, 中野嘉邦 : 3 点法に基づく機上真円度測定法 の改良と $\mathrm{n}$ 点法への拡張，精密工学会誌，56，12(1990) 2303

16) 岸智章, 鴻单健治 : 多点法による形状測定の一搬化, 精密工学会誌, 62, 3(1994) 441

17）原外満，滑川徹，松村文夫 : 3 点法による真円度測定における高次成 分算出の試行, 日本機械学会論文集 (C 編)， 62, 604(1996) 4596.

18）奥山栄樹，守時一: 3 点法真円度測定法における検出子間の特性ずれ の影響, 精密工学会誌, 65, 3 (1999) 447.

19）奥山栄樹, 守時一 : 3 点法による真円度形状測定と軸の回転精度測定 に関する一考察，精密工学会誌，65，9(1999) 1312 .

20) E. Okuyama, K. Goho and K. Mitsui : New analytical method for V-block three-point method, Precision Engineering, 27, 3 (2003) 234.

21）奥山栄樹 : 真円度形状測定と軸の回転精度測定のための一般化された 3 点法への逆行列法の適用について, 精密工学会誌，67，4(2001)649. 